\title{
Polo-like Kinase 1 Inhibitor GSK461364
}

National Cancer Institute

\section{Source}

National Cancer Institute. Polo-like Kinase 1 Inhibitor GSK461364. NCI Thesaurus. Code C70948.

A small molecule Polo-like kinase 1 (PLK1) inhibitor with potential antineoplastic activity. Polo-like kinase 1 inhibitor GSK461364 selectively inhibits Plk1, inducing selective G2/M arrest followed by apoptosis in a variety of tumor cells while causing reversible cell arrest at the G1 and G2 stage without apoptosis in normal cells. Plk1, named after the polo gene of Drosophila melanogaster, is a serine/threonine protein kinase involved in regulating mitotic spindle function in a non-ATP competitive manner. 